\title{
The awareness of urinary tract infection management in pregnant women. A qualitative study
}

\author{
Budi Iman Santoso, Raymond Surya, Farah Asyuri Yasmin, Rima Irwinda \\ Department of Obstetrics and Gynecology, Cipto Mangunkusumo Hospital, Faculty of Medicine, \\ Universitas Indonesia
}

\section{ABSTRAK}

Tujuan: Mengidentifikasi pengetahuan, sikap, dan praktik penyedia layanan kesehatan termasuk dokter umum dan ginekolog dalam penerapan pedoman nasional tentang pengobatan ISK pada ibu hamil.

Bahan dan Metode: Penelitian ini menggunakan desain crosssectional. Subyek adalah wanita yang menghadiri sebuah simposium internasional tentang ISK. Subyek diberi kuesioner penilaian karakteristik demografis, pengetahuan, sikap, dan perilaku. Kuesioner diuji validitas dan reliabilitasnya dengan menerapkan uji korelasi Pearson dan uji alpha Cronbach. Analisis statistik dilakukan dengan menggunakan SPSS 23.0 for Windows. Nilai $p$ two-tailed kurang dari 0,05 dianggap signifikan secara statistik. Hasil: Sebanyak 140 subjek direkrut dalam penelitian ini. Dari jumlah tersebut, 104 subjek $(74,3 \%)$ mengembalikan kuesioner, dan 99 subjek $(70,7 \%)$ memenuhi syarat untuk penelitian ini. Sembilan $(9,1 \%), 69(69,7 \%)$, dan $21(21,2 \%)$ subyek memiliki pengetahuan yang baik, cukup, dan kurang. Enam puluh lima $(65,7 \%)$ dan $64(64,6 \%)$ subjek menunjukkan sikap positif dan memiliki perilaku positif.

Simpulan: Pengetahuan, sikap, dan perilaku subyek cukup baik, meskipun hanya sedikit yang panduan yang telah diperbarui. Pendidikan kesehatan berkelanjutan melalui update atau simposium online bisa menjadi salah satu metode efektif untuk penyebarluasan petunjuk yang baru. (MOG 2017;25:92-96)

Kata kunci: pengetahuan, sikap, perilaku, infeksi salurah kemih

\begin{abstract}
Objectives: to identify knowledge, attitude, and practice of health providers including GPs and gynecologists to the implementation of the national guideline on the treatment of UTI among pregnant women.

Materials and Methods: A cross-sectional study design was used. Subjects were women who attended the International Symposium of UTI. Questionnaires consisting ofregarding demographic characteristics, knowledge, attitude, and practice were given to the subjects. The questionnaires had been tested for validity and reliability by applying the Pearson correlation and Cronbach's alpha test. Statistical analyses were performed using SPSS 23.0 for Windows.A two-tailed p value less than 0.05 was considered to be statistically significant.

Results: A total of 140 subjects were recruited in this study. Of these, 104 subjects $(74.3 \%)$ returned the questionnaire, and 99 subjects $(70.7 \%)$ were eligible for this study. Nine $(9.1 \%), 69$ $(69.7 \%)$, and $21(21.2 \%)$ subjects had good, fair, and poor knowledge, respectively. Sixty-five $(65.7 \%)$ and 64 subjects $(64.6 \%)$ showed a positive attitude and had positive practice, respectively. Conclusion: Knowledge, attitude, and practice among respondents are good enough, despite only a few of them have read the updated guideline. Continuous medical education through online update or symposium may be one effective method to disseminate new update in guidelines. (MOG 2017;25:92-96)
\end{abstract}

Keywords: knowledge, attitude, practice, urinary tract infection.

Correspondence: Rima Irwinda, Department of Obstetrics and Gynecology, Cipto Mangunkusumo Hospital, Faculty of Medicine, Universitas Indonesia. E-mail: rima.irwinda@yahoo.com

\section{INTRODUCTION}

Urinary tract infection (UTI) is one of the most health problems in patients to seek medical care. Its risk is higher among women compared to men due to anatomy which the prevalence more than $10 \%$ of adult women report at least one episode every year. ${ }^{1,2}$ In the United States, approximately 7.9 million people visit general practitioners (GPs) annually due to UTI. ${ }^{3}$ Whereas, in th Netherlands, UTI is the $8^{\text {th }}$ most common reason for GP visits. ${ }^{4}$ In Indonesia, reports regarding the prevalence of UTI are scarce.

One of serious awareness for UTI is during pregnancy. It is usually caused by Escherichia coli. ${ }^{5}$ In general, a pregnant woman had 2-10\% risk of urinary tract infection; whereas $20-40 \%$ was asymptomatic bacteriuria, 1$4 \%$ was acute cystitis case, and $0.5-2 \%$ was pyelonephritis. UTI should be promptly treated as it may lead to several complications including preterm labor, low birth weight, preeclampsia, hypertension, renal failure, and intrauterine fetal death. ${ }^{6}$ During pregnancy, women develop ureteral dilatation, increased bladder tone, and decreased ureteral tone, resulting in increased risk of urinary stasis and uterovesical reflux. Moreover, up to $70 \%$ of pregnant women develop glycosuria, which encourages bacterial growth in the urine. All of these factors contribute to the development of UTI during pregnancy. $^{5}$

To optimize the care of pregnant women with UTI in Indonesia, evidence-based guidelinesare developed across several countries, including in Indonesia under Ikatan Ahli Urologi Indonesia (IAUI) and Himpunan Uroginekologi Indonesia (HUGI). However, adherence to this guideline was still far from optimal. For example, 
in the Netherlands, only $42 \%$ cases of UTI was managed according to the guideline with level of adherence varying from $0-95 \%$ between practices. Reasons underlying the suboptimal practice of GP to the guideline are poorly understood. An analysis of barrier to the implementation is one of the essential strategy to increase the guideline adherence. ${ }^{7}$ This study aims to identify the knowledge, attitude, and practice of health providers including GP and gynecologist to the implementation of the national guideline on UTI treatment in pregnant women. By conducting this study, useful suggestions can become a solution for diagnosis to managing UTI in pregnancy regarding antimicrobial resistance issue.

\section{MATERIALS AND METHODS}

A cross-sectional study was performed to all participants in the International Symposium of Urinary Tract Infection organized by Himpunan Uroginekologi Indonesia (HUGI) on May, 20 ${ }^{\text {th }}$ 2017. Participants who attended this symposium were given questionnaires. Subjects who were willing to participate signed the informed consent and returned the questionnaires. There were five questions of characteristics demographic, Oten questions about knowledge, seven questions of attitude, and five others about practice. We adopted the questionnaire from previously published study. ${ }^{8}$ We developed the questions appropriate to the culture and then translated it into the Indonesian language.

The questions of knowledge included microscopic interpretation for UTI, the definition of asymptomatic bacteriuria, the recommendation of screening, diagnosis, also the treatment of UTI in pregnancy. Scores of 1-3, 4-6, 7-8 were categorized as good, fair, poor know-ledge; respectively. Respondents' attitudes were assessed through several questions concerning in applicating guideline to UTI patients and comment about antibiotic resistance issue. Likert scale was used to assess the attitude including strongly disagree, disagree, agree, and strongly agree.

We considered "negative" attitude for the providers' score less than 17 and "positive" for score equal or more than 17. Respondents' practice was evaluated from several questions regarding habit in diagnosing and treating antibiotic for UTI patients. This was also categorized by the Likert scale of never, sometimes, often, and always. Score equal or more than 11 was considered as positive practice and below it as the negative practice.

Subjects were all participants coming to this symposium ran their practice in Indonesia, they understood Indonesia language well, and returned the questionnaire to be evaluated. Those who did not give service directly to patients were excluded. The independent variables in this study were degree, number of UTI patients handled per week, and having read UTI in pregnancy guideline. Meanwhile, total knowledge, attitude, and practice score were considered as the dependent variables.

Statistical analyses were performed using SPSS 23.0 for Windows. Normality test using Kolgomorov-Smirnow for numerical data. Descriptive analysis was presented in terms of frequency, percentage, median, and minimum-maximum. We categorized the degree into four namely 1 for GP, 2 for OB-GYN, 3 for urologist, and 4 for internist. Meanwhile, number of managing UTI patients per week was divided into 1 for less than five patients, 2 for 5-10 patients, and 3 for more than ten patients.

Awareness for UTI in pregnancy guideline was consisted of 1 for familiar and two not familiar. Validity test with Pearson correlation and reliability test with Cronbach's alpha were done for questions to describe the KAP of UTI in the questionnaire. After all questions were considered valid and reliable, we did the Spearman correlation test to see the association between categorical variables. All p-values were 2-tailed and the significance level selected were lower than 0.05 .

\section{RESULTS AND DISCUSSION}

Of 140 participants attending this symposium, 104 (74.3\%) subjects returned the questionnaires. Of these, only $99(70.7 \%)$ subjects that were eligible for this study. Five subjects were excluded because 3 , 1, one person(s) were microbiologist, pharmacologist, and immunologist; respectively. They did not manage patients directly so that they did not answer the practice concerning UTI patients.

Demographic characteristics of the subjects are presented in Table 1. The questionnaires used in this study had been assessed for theirvalidity reliability before being given to 30 GPs other than the subjects. Several questions were not valid and reliable; however, we still incorporated the questions as were considered them to be essential to determine knowledge, attitude, and practice among respondents. Knowledge, attitude, and practice of respondents concerning to management UTI in pregnancy and antimicrobial resistance issue are presented in Table 2, 3, and 4, respectively. 
Table 1. Demographic characteristics of the subjects $(\mathrm{N}=99)$

\begin{tabular}{|c|c|}
\hline Characteristics & $\mathrm{N}(\%)$ \\
\hline \multicolumn{2}{|l|}{ Age (years old) } \\
\hline - $\quad 21-30$ & $65(65.7)$ \\
\hline - $\quad 31-40$ & $16(16.2)$ \\
\hline - $41-50$ & $10(10.1)$ \\
\hline - $\quad>50$ & $6(6.1)$ \\
\hline - N/A & $2(2.0)$ \\
\hline \multicolumn{2}{|l|}{ Degree } \\
\hline$\bullet \mathrm{GP}$ & $80(80.8)$ \\
\hline - Ob-gyn & $13(13.1)$ \\
\hline - Urologist & $5(5.1)$ \\
\hline - Internist & $1(1.0)$ \\
\hline \multicolumn{2}{|l|}{ Workplace } \\
\hline - Primary healthcarecenter & $0(0)$ \\
\hline - Governmental hospital & $32(32.3)$ \\
\hline - Private hospital & $51(51.5)$ \\
\hline - Clinic & $11(11.1)$ \\
\hline - Own practice & $5(5.1)$ \\
\hline \multicolumn{2}{|l|}{ Number of UTI patients per week } \\
\hline - $<5$ & $52(52.5)$ \\
\hline - $\quad 5-10$ & $39(39.4)$ \\
\hline - $>10$ & $7(7.1)$ \\
\hline - $\quad$ N/A & $1(1.0)$ \\
\hline Read UTI in pregnancy guideline by HUGI & $15(15.2)$ \\
\hline
\end{tabular}

Table 2. Knowledge of UTI management in pregnancy $(\mathrm{N}=99)$

\begin{tabular}{|c|c|}
\hline Questions & $\mathrm{N}(\%)$ \\
\hline \multicolumn{2}{|l|}{ The correct urinary microscopic interpretation(s) for UTI* } \\
\hline $\begin{array}{l}-\quad \geq 10^{3} \mathrm{CFU} / \mathrm{mL} \text { uropathogens on mid-stream urine in uncomplicated acute cystitis of women } \\
\text { (TRUE) }\end{array}$ & $37(35.6)$ \\
\hline - $\quad \geq 10^{4} \mathrm{CFU} / \mathrm{mL}$ uropathogens on mid-stream urine of men (TRUE) & $32(30.8)$ \\
\hline - $\quad \geq 10^{5} \mathrm{CFU} / \mathrm{mL}$ uropathogenson mid-stream urine of women (TRUE) & $74(71.2)$ \\
\hline \multicolumn{2}{|l|}{ The correct statement(s) below } \\
\hline - A 28-year-old pregnant woman having asymptomatic bacteriuria needs an antibiotic (TRUE) & $42(45.2)$ \\
\hline $\begin{array}{l}\text { - Asymptomatic bacteriuria is a growth of } \geq 10^{5} \mathrm{CFU} / \mathrm{ml} \text { uropathogens on two consecutive mid- } \\
\text { stream urine in }>24 \text { hours without any symptoms (TRUE) }\end{array}$ & $78(75.0)$ \\
\hline - On pregnant women, bacteriuria screening is recommended in every antenatal care (FALSE)* & $50(48.1)$ \\
\hline $\begin{array}{l}\text { - Urinary culture should be performed in pregnant women due to less meaningful of dipstick } \\
\text { urinalysis (FALSE)* }\end{array}$ & $65(62.5)$ \\
\hline - The indicator of urinary dipstick screening is leucocyte esterase and nitrite (TRUE)* & $92(88.5)$ \\
\hline - E.coliis the most common pathogen causing UTI on outpatient, inpatient, and pregnant women & $92(88.5)$ \\
\hline $\begin{array}{l}\text { TRUE) } \\
\text { - Trimethoprim can be used in the first trimester to manage UTI for five days (FALSE) }\end{array}$ & $62(59.6)$ \\
\hline Single dose fosfomycin can be used to manage UTI in each trimester (TRUE)* & $47(452)$ \\
\hline $\begin{array}{l}\text { - Pregnant women with previous history of recurrent UTI should be administered withprophylaxis } \\
\text { antibiotic (TRUE)* }\end{array}$ & $67(64.4)$ \\
\hline
\end{tabular}

\footnotetext{
* Valid and reliable questions

$\mathrm{CFU}=$ colony forming unit
} 
Table 3. Attitude towards to UTI management in pregnancy and antimicrobial resistance issue (N=99)

\begin{tabular}{lllll}
\hline \multicolumn{1}{c}{ Statement(s) } & \multicolumn{1}{c}{ SD } & \multicolumn{1}{c}{ D } & A & SA \\
\hline I feel confident to manage UTI in pregnancy appropriate to guideline* & $0(0)$ & $13(13.1)$ & $65(65.7)$ & $21(21.2)$ \\
Guideline recommendation is applicable to my patients* & $5(5.1)$ & $23(23.2)$ & $59(59.6)$ & $12(12.1)$ \\
Guideline recommendation is essential for daily clinical practice & $0(0)$ & $3(3.0)$ & $57(57.6)$ & $39(39.4)$ \\
Changes in urine color and smell needs to be evaluated through urine culture & $3(3.0)$ & $25(25.3)$ & $45(45.5)$ & $26(26.3)$ \\
& & & & \\
examination* & $14(14.1)$ & $32(32.3)$ & $35(35.4)$ & $18(18.2)$ \\
Asymptomatic bacteriuria in pregnancy shouldbe treated withantibiotic* & $12(12.1)$ & $39(39.4)$ & $38(38.4)$ & $10(10.1)$ \\
Recurrent UTI frequentlyoccurs in pregnant women* & $0(0)$ & $1(1.0)$ & $49(49.5)$ & $49(49.5)$ \\
Nowadays, I pay attention to the antibiotic resistance issue* & & &
\end{tabular}

SD: Strongly disagree; D: Disagree; A: Agree; SA: Strongly agree

* Valid and reliable questions

Table 4. Practice towards to UTI management in pregnancy and antimicrobial resistance issue $(\mathrm{N}=99)$

\begin{tabular}{lllll}
\hline \multicolumn{1}{c}{ Statement(s) } & \multicolumn{1}{c}{$\mathrm{N}$} & \multicolumn{1}{c}{$\mathrm{S}$} & $\mathrm{O}$ & $\mathrm{A}$ \\
\hline Before prescribing antibiotic, I usually perform urinary dipstick or urinalysis & $2(2.0)$ & $14(14.1)$ & $42(42.4)$ & $40(40.4)$ \\
I would ask for urinary culture whether there is a change of urine color or & $16(16.2)$ & $37(37.4)$ & $29(29.3)$ & $16(16.2)$ \\
smell* & & & & \\
I would prescribe antibiotic to all bacteriuria with symptoms patients* & $1(1.0)$ & $1(1.0)$ & $38(38.4)$ & $58(58.6)$ \\
In managing UTI, I only administer oral antibiotic for seven days* & $1(1.0)$ & $10(10.1)$ & $61(61.6)$ & $26(26.3)$ \\
I ask urinary culture examination for pregnant women* & $34(34.3)$ & $41(41.4)$ & $17(17.2)$ & $6(6.1)$ \\
\hline N: Never; S: Sometimes; O: Often; A: Always & & &
\end{tabular}

Knowledge was categorized as good, fair, and poor, whereas both attitude and practice were divided into positive and negative. There were $9(9.1 \%), 69(69.7 \%)$, and $21(21.2 \%)$ subjects that had good, fair, and poor knowledge, respectively. Sixty-five $(65.7 \%)$ subjects showed positive attitude and $64(64.6 \%)$ subjects had positive practice, whereas knowledge did not significantly associatedwith attitude and practice $(\mathrm{p}=0.140$, $\mathrm{r}=0.149$, and $\mathrm{p}=0.321 ; \mathrm{r}=0.101$, respectively). In addition, attitude was not significantly associated with practice $(\mathrm{p}=0.331 ; \mathrm{r} 0.099)$.

One limitation of this study was the unequal distribution among health practitioners. Most of the questionnaires were filled by GPs;thus, it could be difficult to determine the knowledge, attitude, and practice of obstetricians and gynecologist towards to UTI management in pregnancy and antimicrobial resistance issue. However, this was the first study concerning the health practitioner adherence to UTI guideline by HUGI and antimicrobial resistance issue. This study resulted most respondents had fair to good knowledge of management UTI in pregnancy $(78.8 \%)$. However, knowledge regarding the management of UTI among pregnant patients such as asymptomatic bacteriuria requiring therapy, timing of bacteriuria screening in, and single dose fosfomycin as treatment in each trimester were still poor. However, they felt confident to manage UTI in pregnancy and they felt that the guideline was applicable their patients. Actually, all recommendations from diagnosis to treatment for UTI in pregnancy had been released by HUGI in $2015 .{ }^{6}$ Unfortunately, the respondents whom most of them were GP did not read the guideline; only $15.2 \%$ revealed that they have ever read the guideline. Therefore, the knowledge to updated guideline can be a barrier to attitude and practice in prescribing the most effective drug for patients.Raising awareness among GPs to adhere to the guideline will change their current practice. Educational program containing knowledge transfer such as symposium may be effective to introduce the updated guideline. ${ }^{7}$

The low adherence to our study such as a must to treat asymptomatic bacteriuria in pregnancy with antibiotic was not different from several international studies. ${ }^{9-}$ ${ }^{11}$ The other studies showed the low adherence to different UTI management with wide variation in the interpretation of sign and symptoms, using different diagnostic test and antibiotic, also performing follow up to the patients. A study at the Mayo Clinic in the US demonstrated that only $30 \%$ of uncomplicated UTI patients were treated using standardized management in line with the national guideline. ${ }^{10,11}$

Nowadays, bacterial resistance has raise the awareness of health providers. This study showed that $99 \%$ respondents considered antimicrobial resistance was important. ${ }^{12,13}$ However, the resistance patterns may differ among regions. Florian $\mathrm{F}$, et al. ${ }^{14}$ through their studies suggested that strategies inimplementing theguideline through active learning from experts as opinion leaders and continuing education through continuous medical education (CME) as useful tools for improving physicians' knowledge regarding antibiotic resistance issue. Furthermore, in establishing a guideline, complexity, layout, accessibility, and applicability should be considered so that the guidelines become short and userfriendly as possible. This study revealed that the 
majority of the respondents have performed minimal urinalysis or urine dipstick testing before administering antibiotics $(82.8 \%)$ to the patients. They only prescribed antibiotics for maximum seven days $(87.9 \%)$. It was in appropriate to the issue of antibiotic resistance awareness. Different from study by Ingeborg B, et al. ${ }^{15}$ in Sweden found thatonly GPs who were aware to antibiotic resistance would prescribe antibiotic following to the guideline completely. Another study ${ }^{16}$ also stated that physicians stressed to accurate diagnosis and avoiding unnecessary treatment would use supporting examination (urine culture, microscopic urinalysis, follow-up visit and test, prolonged antibiotic treatment) in managing UTI patients. Therefore, practice of GP's in managing UTI by concerning to antibiotic resistance would be important to improve health quality.

\section{CONCLUSION}

The knowledge, attitude, and practice among respondents are good enough, despite only a few of them have read the updated guideline. Therefore, continuous medical education through online update or symposium can be one of the methods to disseminate new update in guidelines.

\section{REFERENCES}

1. Foxman B. Epidemiology of urinary tract infections: incidence, morbidity, and economic costs. The Am Jour of Med. 2002;113(1A):5S-13S.

2. Forxman B, Barlow R, D'Arcy H, et al. Urinary tract infection: Self-reported incidence and associated costs. Am Epid. 2000;10(8):509-15.

3. Schappert SM and Burt CW. Ambulatory care visits to physician offices, hospital outpatient departments, and emergency departments United States, 2001-02. National Center for Health Statistics. Vital Health Stat. 2006;13:1-66.

4. Verheij LJ, Abrahamse H, Van den Hoogen H. Feitenencijfers over huisartsenzorg in Nederland Utrecht: Landelijk Informatie netwerk Huisartsenzorg (LINH); 2004.

5. Ahmed MH. Effect of intervention guidelines on self-care practices of pregnant women with urinary tract infection. Life Sci Jour. 2015;12(1).
6. Himpunan Uroginekologi Indonesia. Pedoman Nasional Pelayanan Kedokteran (PNPK). Infeksi saluran kemih. 2015.

7. Lugtenberg M, Burgers JS, Schaick JMZ, Westert GP. Guidelines on uncomplicated urinary tract infections are difficult to follow: perceived barriers and suggested interventions. BMC Family Practice. 2010;11:51.

8. Trautner BW, Petersen NJ, Hysong SJ, et al. Overtreatment of asymptomatic bacteriuria: Identifying provider barriers to evidence-based care. American Journal of Infection Control. 2014; 42:653-8.

9. Stewart KE. An audit of management of acute uncomplicated lower UTI at a health centre in Central Scotland. Scottish Universities Medical Journal. 2012.

10. Grover ML, Bracamonte JD, Kanodia AK, et al. Assessing adherence to evidence-based guidelines for the diagnosis and management of uncomplicated urinary tract infection. Mayo Clin Proc. 2007; 82(2):181-185.

11. Grigoryan L, Zoorob R, Wang H, Trautner BW. Low concordance with guidelines for treatment of acute cystitis in primary care. Open Forum Infect Dis. 2015;2(4):159.

12. Wagenlehner FME, Weidner W, Naber KG. An update on uncomplicated urinary tract infections in women. Curr Opin Urol. 2009; 19:368-74.

13. Mangin D, Toop L, Chambers S, et al. Increased rates of trimethoprim resistance in uncomplicated urinary tract infection: Cause for concern? NZ Med J. 2005;118:U1726.

14. Fischer F, Lange $\mathrm{K}$, Klose $\mathrm{K}$, et al. Barriers and strategies in guideline implementation-a scoping review. Healthcare. 2016;4:36.

15. Bjorkman I, Berg J, Viberg N, Lundborg CS. Awareness of antibiotic resistance and antibiotic prescribing in UTI treatment: A qualitative study among primary care physicians in Sweden. Scandinavian Journal of Primary Health Care. 2013;31: 50-5.

16. Flach SD, Longenecker JC, Tape TG, et al. The relationship between treatment objectives and practice patterns in the management of urinary tract infections. Journal of the Society for Medical Decision Making 2003;23:131-9. 